\title{
Evaluation of renal cyst treatment using retroperitoneal laparoscopic decortication
}

\author{
Ut Thanh $\mathrm{Ho}^{1}$, Cuong Van Dam ${ }^{2,3}$, Nghiep Ke Le $\mathrm{L}^{3,4, *}$
}

${ }^{1}$ Phuong Chau International Hospital, Can Tho City, Viet Nam

${ }^{2}$ Can Tho University of Medicine and Pharmacy, Can Tho City, Viet Nam

${ }^{3}$ Faculty of Public Health of Mahasarakham University, Thailand

${ }^{4}$ Tam Binh District Health Center, Tam Binh District, Vinh Long Province, Viet Nam

\section{Correspondence}

Nghiep Ke Le, Faculty of Public Health of Mahasarakham University, Thailand

Tam Binh District Health Center, Tam Binh District, Vinh Long Province, Viet Nam

Email: lekenghiep@gmail.com

\section{History}

- Received: Aug 02, 2020

- Accepted: Jan 12, 2021

- Published: Jan 31, 2021

DOI : 10.15419/bmrat.v8i1.659

\section{Check for updates}

\section{Copyright}

(-) Biomedpress. This is an openaccess article distributed under the terms of the Creative Commons Attribution 4.0 International license.

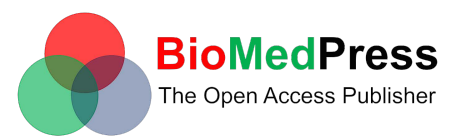

\begin{abstract}
Introduction: Renal cysts are a common disease of the renal parenchyma. The management options include percutaneous aspiration with or without sclerotherapy, open surgery, and the laparoscopic decortication of the renal cyst. Laparoscopic renal cyst decortication is a safe and effective alternative with a high success rate. This study aimed to evaluate renal cyst treatment by retroperitoneal laparoscopic decortication. Methods: This was a prospective study of patients with an asymptomatic renal cyst size greater than $60 \mathrm{~mm}$ or a symptomatic renal cyst size less than $60 \mathrm{~mm}$ in their greatest dimension. The patients underwent retroperitoneal laparoscopic decortication and were admitted to the University Hospital, Can Tho General Hospital (Viet Nam), and Can Tho Central General Hospital (Viet Nam) from September 2018 to May 2020. The renal cysts were localized and characterized by ultrasonography and computed tomography (CT). The symptomatic success rate, radiologic success rate, and any complications as part of the procedure were noted. Each patient was reassessed with clinical and ultrasonography examinations at 3 months postoperatively. Results: 33 patients underwent retroperitoneal laparoscopic cyst decortication. This included 11 males (33.3\%) and 22 females (66.7\%). The mean age of the patients was 58.48 \pm 9.36 years. Flank pain was a common clinical symptom at presentation in all patients. Most of the cysts were located in the left kidney (39.4\%), in the lower pole (54.6\%), and in a single cyst (87.9\%). The mean cyst diameter was $80.09 \pm 27.03 \mathrm{~mm}$. The cysts were classified as I using the Bosniak classification. The mean operative time was $69.39 \pm 16.94$ minutes. The operative time in the patients with a cyst diameter $\geq 60 \mathrm{~mm}$ was statistically significantly longer than in the patients with a cyst diameter $<60 \mathrm{~mm}(\mathrm{p}=0.004)$. The mean hospital stay time was $8.24 \pm 2.84$ days. Symptomatic success was achieved in $90.1 \%$ of patients and radiographic success on ultrasonography was achieved in $84.8 \%$. The operation was successfully completed by laparoscopy in all cases. Conclusion: Retroperitoneal laparoscopic cyst decortication is effective for the treatment of renal cysts. The operation was successfully completed via laparoscopy in all cases.

Key words: cyst decortication, renal cyst, retroperitoneal laparoscopic
\end{abstract}

\section{INTRODUCTION}

Simple renal cysts are a common non-neoplastic disease of the renal parenchyma. It has been estimated that the prevalence of renal cysts increases with age. The management options for renal cysts include percutaneous aspiration with or without sclerotherapy, open surgery, and laparoscopic cyst peeling ${ }^{1-3}$. Simple aspiration or sclerotherapy is a minimally invasive procedure. However, the recurrence rate is very high. Open surgery offers a high success rate but it is an invasive procedure with the comorbidity of flank incision $^{4,5}$. The laparoscopic technique not only has a high success rate. It is also characterized by minimal invasiveness, low morbidity, and early recuperation, making it a preferred treatment ${ }^{4,5}$. This method has been widely applied in Vietnam, in general, and Can Tho city, in particular ${ }^{6,7}$. In fact, the Can Tho University of Medicine and Pharmacy Hospital, Can
Tho General Hospital, and Can Tho Central General Hospital have performed retroperitoneal laparoscopic decortication for renal cysts for over 9 years. Nevertheless, there have been no reports to evaluate the efficacy of this method in renal cyst treatment. The aim of this study was therefore to investigate the efficacy of renal cyst treatment by retroperitoneal laparoscopic decortication.

\section{METHODS}

\section{Patients}

This was a prospective study of renal cyst patients who underwent retroperitoneal laparoscopic decortication and were admitted to the University Hospital, Can Tho General Hospital, and Can Tho Central General Hospital from September 2018 to May 2020. All patients who agreed to participate in the study were confirmed by signing a consent form for the study. 


\section{Inclusion criteria}

The surgery indicators included patients with an asymptomatic renal cyst size greater than $60 \mathrm{~mm}$ or with a symptomatic cyst (such as renal pain, a renal lump, hypertension, or hematuria), and a renal cyst size less than $60 \mathrm{~mm}$ in the greatest dimension for simple cysts (Bosniak I and II classification).

\section{Exclusion criteria}

Patients were excluded if they had a history of previous renal surgery or complicated cysts (Bosniak III and IV), or an asymptomatic cyst size less than $60 \mathrm{~mm}$ in the greatest dimension.

\section{Procedure}

The renal cysts were localized and characterized by an ultrasonography and computed tomography (CT). The symptomatic success rate, radiologic success rate, and complication of procedure were noted. Each patient was reassessed using clinical and ultrasonography examinations at 3 months postoperatively.

After the induction of general anesthesia, the patient was catheterized and positioned in the standard left/right lateral decubitus position. All patients were successfully managed by retroperitoneal laparoscopic decortication using a 3-port technique. The first port was inserted $1 \mathrm{~cm}$ below and posterior to the tip of the $12^{\text {th }}$ rib. A $2 \mathrm{~cm}$ deep stab incision was made down to the thoracolumbar fascia and a homemade balloon was created by tying a fingerstall surgeon glove, inflated with 200 to $300 \mathrm{~mL}$ air, and it was kept for about 5 minutes to create an adequate working space in the retro-peritoneum. After deflating the balloon at the retroperitoneal end, it was removed. A 1.0 $\mathrm{cm}$ blunt-tip trocar was then placed and a 30-degree laparoscope was inserted through the sheath. Carbon dioxide was insufflated to $12 \mathrm{mmHg}$ and the initial retroperitoneoscopy was performed for the orientation and confirmation of the anatomic landmarks. Two working ports $(0.5$ and $1.0 \mathrm{~cm}$, respectively) were placed under laparoscopic camera. At one lumbar angle, grasping forceps were inserted, and at another angle more anteriorly (along or more medial to the anterior axillary line, at least $3 \mathrm{~cm}$ above the iliac crest to allow maneuverability), a dissecting forceps or clip applier was inserted via the trocar. The direction of dissection depended on the location of the renal cyst (anterior, posterior, or central aspect; upper, middle, or lower pole). Gerota's fascia was incised over the area corresponding to the position of the cyst. The overlying perinephric fat was dissected from the cyst and the surrounding parenchyma. The cyst was then unroofed 1 to $1.5 \mathrm{~cm}$ adjacent to the renal parenchyma, leaving behind the floor of the cyst. The cyst fluid was aspirated and the cystic wall was sent for pathological analysis. Subsequently, the 18 French catheter used for drainage was placed in the retro-peritoneum and the port sites were cleansed and closed.

\section{Statistical Analysis}

Statistical analysis was performed using the commercially available statistical program (SPSS 20.0) in addition to the Pearson $\chi^{2}$ and Student's $t$ test for the independent variables; $\mathrm{p}<0.05$ was considered to be statistically significant.

\section{Study Ethics}

The study was reviewed and approved for implementation by Can Tho University of Medicine and Pharmacy under Decision No. 451/Decision-CTUMP (dated 20 March 2018).

\section{RESULTS}

In total, 33 patients underwent retroperitoneal laparoscopic cyst decortication. This included 11 males (33.3\%) and 22 females (66.7\%). The mean age of the patients was $58.48 \pm 9.36$ years, as shown in Table 1 . Flank pain was a common clinical symptom at presentation in all patients. Most of the cysts were located in the left kidney (39.4\%), in the lower pole (54.6\%), and in a single cyst (87.9\%). The mean cyst diameter was $80.09 \pm 27.03 \mathrm{~mm}$ with a cyst diameter $\geq 60 \mathrm{~mm}$ in $87.9 \%$. The cysts were classified as I using the Bosniak classification.

Most of the cysts were located in the left kidney (39.4\%), followed by the right kidney (30.3\%) and bilateral kidney (30.3\%) with $\chi^{2}=0.545$ and $\mathrm{p}=0.761$, indicating no statistically significant difference. Most of the cysts were located in the lower pole (54.6\%), followed by the upper pole (42.4\%) and peripelvic (3\%), with $\chi^{2}=14.364$ and $\mathrm{p}=0.001$, indicating that the differences were statistically significant. Specifically, $87.9 \%$ of patients had only 1 cyst and $12.1 \%$ had 2 cysts $\left(\chi^{2}=18.939, \mathrm{p}<0.001\right)$. The results were considered to be statistically significant.

The mean cyst diameter was $80.09 \pm 27.03 \mathrm{~mm}$ which included a cyst diameter $\geq 60 \mathrm{~mm}$ in $87.9 \%$ of patients and a cyst diameter $<60 \mathrm{~mm}$ in $12.1 \%$ patients (with $\chi^{2}=18.939, \mathrm{p}<0.001$; the differences were statistically significant). All of the cysts were classified as I using the Bosniak classification. The mean operative time was $69.39 \pm 16.94$ minutes. The operative time in patients with a cyst diameter $\geq 60 \mathrm{~mm}$ was 


\section{Table 1: Patient characteristics and preoperative parameters}

\begin{tabular}{|c|c|c|}
\hline Characteristics & & $\mathrm{N}(\%)$ \\
\hline \multirow[t]{2}{*}{ Gender (n, \%) } & Male & $11(33.3 \%)$ \\
\hline & Female & $22(66.7 \%)$ \\
\hline Mean age (range) (year) & & $58.48(39-83)$ \\
\hline \multirow[t]{5}{*}{ Clinical presentation (n, \%) } & Flank pain & $23(69.7 \%)$ \\
\hline & Flank pain and renal lump & $2(6.06 \%)$ \\
\hline & Flank pain and dysuria & $4(12.1 \%)$ \\
\hline & Flank pain and hematuria & $2(6.06 \%)$ \\
\hline & Flank pain,renal lump and hematuria & $2(6.06 \%)$ \\
\hline \multirow[t]{3}{*}{ Kidney side (n,\%) } & Right & $10(30.3 \%)$ \\
\hline & Left & $13(39.4 \%)$ \\
\hline & Bilateral & $10(30.3 \%)$ \\
\hline \multirow[t]{4}{*}{ Cyst location (n, \%) } & Upper & $14(42.4 \%)$ \\
\hline & Middle & $0(0 \%)$ \\
\hline & Lower & $18(54.6 \%)$ \\
\hline & Peripelvic & $1(3.0 \%)$ \\
\hline Maximum diameter of cyst (mm) & & $80.09 \pm 27.03$ \\
\hline \multirow[t]{2}{*}{ Diameter of cyst (n, \%) } & $\geq 60 \mathrm{~mm}$ & $29(87.9 \%)$ \\
\hline & $<60 \mathrm{~mm}$ & $4(12.1 \%)$ \\
\hline \multirow[t]{2}{*}{ Number of cysts (n, \%) } & 1 & $29(87.9 \%)$ \\
\hline & 2 & $4(12.1 \%)$ \\
\hline \multicolumn{3}{|l|}{ Bosniak classification (n) } \\
\hline I & & $33(100 \%)$ \\
\hline
\end{tabular}

Table 2: Perioperative results and follow-up

\begin{tabular}{|c|c|c|}
\hline \multicolumn{2}{|c|}{ Perioperative results and follow-up } & Data \\
\hline \multicolumn{2}{|c|}{ Operative time (minute) } & $69.39 \pm 16.94$ \\
\hline \multicolumn{2}{|c|}{ Operative time in patients with cyst diameter $\geq 60 \mathrm{~mm}$ (minute) } & $71.03 \pm 17.39$ \\
\hline \multicolumn{2}{|c|}{ Operative time in patients with cyst diameter $<60 \mathrm{~mm}$ (minute) } & $57.5 \pm 5.0$ \\
\hline \multicolumn{2}{|c|}{ Blood loss (range) (ml) } & $5-20$ \\
\hline \multicolumn{2}{|c|}{ Hospitalization time (day) } & $8.24 \pm 2.84$ \\
\hline \multicolumn{2}{|l|}{ Complication } & 0 \\
\hline \multirow[t]{2}{*}{ Pathologic analysis } & Benignancy & 33 \\
\hline & Malignancy & 0 \\
\hline \multicolumn{2}{|c|}{ Mean length of follow-up (month) } & 3 \\
\hline \multicolumn{2}{|c|}{ Mean diameter of cyst after 3 months (range) (mm) } & 3.21 \\
\hline \multicolumn{2}{|c|}{ Symptomatic success (\%) } & 81.9 \\
\hline \multicolumn{2}{|c|}{ Radiologic success (\%) } & 84.8 \\
\hline
\end{tabular}


longer than that of patients with a cyst diameter $<60$ $\mathrm{mm}$ ( $\mathrm{p}=0.004$; the difference was statistically significant). The mean hospital stay time was $8.24 \pm 2.84$ days. Symptomatic success was achieved in $90.1 \%$ of patients and radiographic success on ultrasonography was achieved in $84.8 \%$. The operation was successfully completed via laparoscopic in all cases with no conversion to open surgery, in addition to no mortality and no complications in this study (Table 2).

\section{DISCUSSION}

Flank pain was a common clinical symptom upon presentation in all patients. This was a major symptom in other reports such as the work of Okan $(79.9 \%)^{8}$ and Dinh Le Quy Van $(89.5 \%)^{7}$. Most of the cysts were located in the left kidney (39.4\%), followed by the right kidney (30.3\%) and bilateral kidney $(30.3 \%)$, with $\chi^{2}=0.545, \mathrm{p}=0.761$. The results were not considered to be statistically significant. These results are similar to those of other reports, such as the published studies by Nguyen Ngoc Anh $(52.78 \%)^{6}$, Dinh Le Quy Van $(42.1 \%)^{7}$, and Shicong Lai $(55,1 \%)^{9}$. Most of the cysts were located in the lower pole (54.6\%), followed by the upper pole $(42.4 \%)$ and peripelvic (3\%), with $\chi^{2}=14.364, \mathrm{p}=$ 0.001 .

Our study was similar to the other published reports. In our study, lower pole cysts were also common as in the reports by Nguyen Ngoc Anh $(44.4 \%)^{6}$, Dinh Le Quy Van $(44.7 \%)^{7}$, and Okan $(32.8 \%)^{8}$. Note that $87.9 \%$ of patients had only 1 cyst and that $12.1 \%$ had 2 cysts $\left(\chi^{2}=18.939, \mathrm{p}<0.001\right)$. This indicates that the observed differences were considered to be statistically significant. Thus, our study had similar results to the other reports.

The mean cyst diameter was $80.09 \pm 27.03 \mathrm{~mm}$. This included a cyst diameter $\geq 60 \mathrm{~mm}$ in $87.9 \%$ and a cyst diameter $<60 \mathrm{~mm}$ in $12.1 \%$ with $\chi^{2}=18.939$, $\mathrm{p}<0.001$ (considered to be a statistically significant difference). The diameter of the kidney cysts in our study were larger than those in the studies by Okan Bas (2015) (78.8 $\left.\pm 17.2 \mathrm{~mm}^{8}\right)$, Shicong Lai (2017) $\left(66.9 \pm 16.2 \mathrm{~mm}^{9}\right)$, Nguyen Ngoc Anh (2016) (77.25 $\pm 16.8 \mathrm{~mm}^{6}$ ), and Dinh Le Quy Van (2018) (69.3 \pm $21.3 \mathrm{~mm}^{7}$ ).

The mean operative time was $69.39 \pm 16.94$ minutes. The operative time in patients with a cyst diameter $\geq$ $60 \mathrm{~mm}$ was longer than in patients with a cyst diameter $<60 \mathrm{~mm}$ with $\mathrm{p}=0.004$ ( $\mathrm{p}<0.05$ was considered to be a statistically significant difference). Our study was similar to the reports by Shicong Lai (2017) (66.89 \pm 22.68 min $^{9}$, Nguyen Ngoc Anh (2016) (57.28 \pm $\left.14.1 \mathrm{~min}^{6}\right)$, and Dinh Le Quy Van (2018) $(79.4 \pm 23.3$ $\min ^{7}$ ).

There was found to be a relationship between operative time and cyst diameter in our study. The operative time of a cyst diameter $<60 \mathrm{~mm}$ was 57.5 $\pm 5.0 \mathrm{~min}$ and the operative time of a cyst diameter $\geq 60 \mathrm{~mm}$ was $71.03 \pm 17.39$ which was $\mathrm{p}=$ 0.004 (considered to be a statistically significant difference). The operation was successfully completed laparoscopically in all cases with no conversion to open surgery, no mortality and no complications observed throughout the study. The mean hospital stay time was $8.24 \pm 2.84$ days. The hospital stay time in our study was longer than the hospital stay time in the work of Shicong Lai $(4.81 \pm 1.25 \text { days })^{9}$. The mean follow-up time was 3 months. The mean diameter of the cysts was $80.09 \pm 27.03 \mathrm{~mm}$ before operating and the mean diameter of the cysts was 3.21 $\mathrm{mm}$ at 3 months post-operatively with $\mathrm{Z}=-5.013, \mathrm{n}$ $=33, \mathrm{P}<0.001$ (considered to be statistically significant). Symptomatic success was achieved in $90.1 \%$ of patients. This result was lower than that of the other reports such as the work of Okan $(92.6 \%)^{8}$ and Dinh Le Quy Van $(96.4 \%)^{7}$. Radiographic success on ultrasonography was achieved in $84.8 \%$. This result is lower than that stated by other reports, such as the work of Okan $(96.6 \%)^{8}$ and Dinh Le Quy Van $(96.4 \%)^{7}$.

\section{CONCLUSIONS}

Retroperitoneal laparoscopic cyst decortication is effective for the treatment of renal cysts. The average surgery time was quite reasonable. The operation was successfully completed laparoscopically in all cases with no conversion to open surgery, no mortality and no complications observed in this study. Symptomconnected and ultrasound success have been achieved at a very high level. However, a larger sample size is needed and a longer patient follow-up time is required to confirm the effectiveness of this method.

\section{ABBREVIATIONS}

None

\section{ACKNOWLEDGMENTS}

We would like to thank the leaderships of Can Tho University of Medicine and Pharmacy, the school's scientific council for allowing us to conduct this research. At the same time, we would like to express our sincere thanks to the leadership and colleagues of three hospitals including University Hospital, Can Tho General Hospital, and Can Tho Central General 
Hospital for their dedicated help in the process of collecting research data. In particular, we would like to express our sincere thanks to the patients who volunteered to participate in our research.

\section{AUTHOR'S CONTRIBUTIONS}

UTH: The main study author designed the study, found references, collected and analyzed data, and wrote and reported the research results. CVD: Coauthor and supervisor edited and contributed the research ideas. NKL: Co-author revised the article and supported the data. All authors read and approved the final manuscript.

\section{FUNDING}

None

\section{AVAILABILITY OF DATA AND MATERIALS}

Data and materials used and/or analyzed during the current study are available from the corresponding author on reasonable request.

\section{ETHICS APPROVAL AND CONSENT TO PARTICIPATE}

This study was conducted in accordance with themamended Declaration of Helsinki. The institutional review board approved the study, and all participants provided written informed consent.

\section{CONSENT FOR PUBLICATION}

Not applicable.

\section{COMPETING INTERESTS}

The authors declare that they have no competing interests.

\section{REFERENCES}

1. Kovacević DO, Popić-Ramac J, Vidjak V. Ultrasound guided percutaneous sclerotherapy of simple renal cysts: primary success and procedure safety. Lijec Vjesn. 2015;137(11-12):364-6. PMID: 26975066.

2. Choi JD, Yoo TK, Kang JY, Moon KT, Kim JH, Ahn SH, et al. A Comparative Study of Percutaneous Aspiration with Sclerotherapy and Laparoscopic Marsupialization for Symptomatic Simple Renal Cysts. J Laparoendosc Adv Surg Tech A. 2020;30(5):5149. PMID: 31928507. Available from: 10.1089/lap.2019.0745.

3. Yonguc T, Sen V, Aydogdu O, Bozkurt IH, Yarimoglu S, Polat S. The comparison of percutaneous ethanol and polidocanol sclerotherapy in the management of simple renal cysts. Int Urol Nephrol. 2015;603-7(4):47.

4. Nalagatla S, Manson R, McLennan R, Somani B, Aboumarzouk OM. Laparoscopic Decortication of Simple Renal Cysts: A Systematic Review and Meta-Analysis to Determine Efficacy and Safety of this Procedure. Urol Int. 2019;103(2):235-41. PMID: 30889610. Available from: 10.1159/000497313.

5. Lai S, Xu X, Diao T, Jiao B, Jiang Z, Zhang G. The efficacy of retroperitoneal laparoscopic deroofing of simple renal cyst with perirenal fat tissue wadding technique: A retrospective study. Medicine (Baltimore). 2017;96(41):e825. Available from: 10.1097/MD.0000000000008259.

6. Anh NN. Nghiên cứu đặc điểm lâm sàng, cận lâm sàng và kết quả điều trị nang thận bằng phương pháp phẫu thuật nội soi tại Bệnh viện Đa khoa Trung ương Cần Thơ và Bệnh viện Đa khoa Thành phố Cần Thơ, Bachelor Clinical Medicine, Faculty of Medicine, Can Tho University of Medicine and Pharmacy, 2016 (In Vietnamese).

7. Van DL. Đánh giá kết quả chẩn đoán và điều trị bệnh lý nang thận theo phân loại Bosniak, Resident Doctor, Faculty of Medicine, University of Medicine and Pharmacy at HCMC, 2018 (In Vietnamese).

8. Bas O, Nalbant I, Sener NC, Firat H, Yesil S, Zengin K, et al. Management of renal cysts. JSLS. 2015;19(1):e2014.00097. PMID: 25848184. Available from: 10.4293/JSLS.2014.00097.

9. Lai S, Xu X, Diao T, Jiao B, Jiang Z, Zhang G. The efficacy of retroperitoneal laparoscopic deroofing of simple renal cyst with perirenal fat tissue wadding technique: A retrospective study. Medicine (Baltimore). 2017;96(41):e8259. PMID: 29019896. Available from: 10.1097/MD.0000000000008259. 
Ready to submit your manuscript? Choose Biomedpress and benefit from:

- Fast, convenient online submission

- Through peer-review by experienced researchers

- Rapid publication on acceptance

- Free of charge (without publication fees)

Learn more http://www.biomedpress.org/journals/

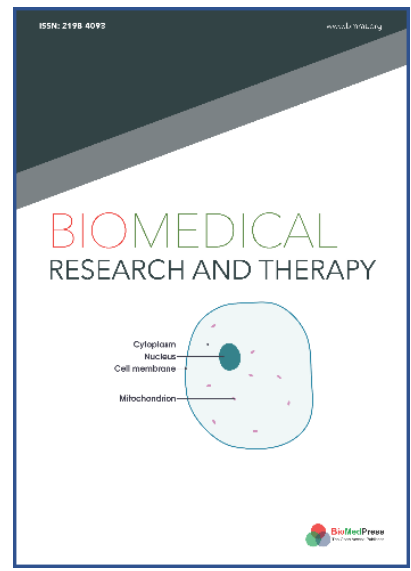

\title{
Biomedical Research and Therapy
}

Indexed: Web of Science (ESCl), Embase, Google Scholar

Journal Citation Indicator (2020): 0.16

Acceptance Rate (2020): 54.32\%

Article Publishing Charge: Free

Submission to first editorial decision: 27 days

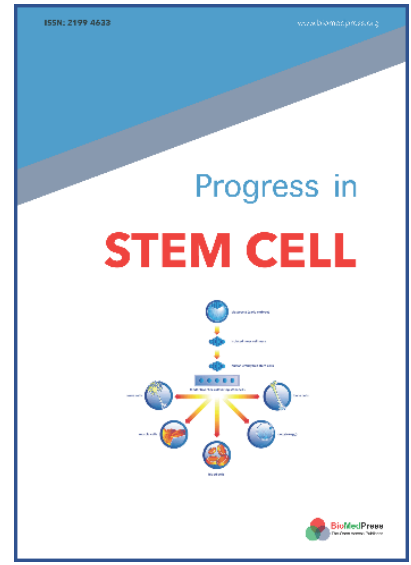

\section{Progress in Stem Cell}

Indexed: Embase, Google Scholar

Acceptance Rate (2020): 78.19\%

Article Publishing Charge: Free

Submission to first editorial decision: 19 days

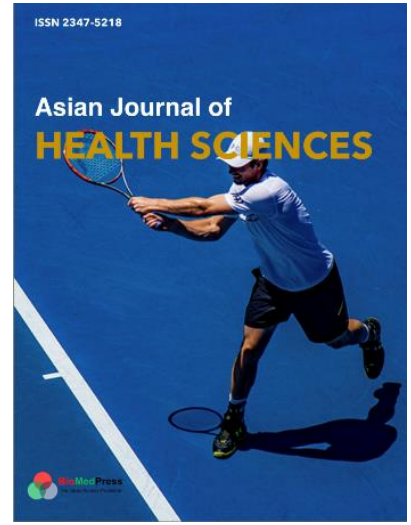

\author{
Asian Journal of Health Sciences \\ Indexed: Google Scholar \\ Acceptance Rate (2020): 72.89\% \\ Article Publishing Charge: Free \\ Submission to first editorial decision: 16.5 days
}

